\section{Sex Determination in Mythology and History}

\section{ABSTRACT}

The history of ideas on how the sexes became divided spans at least three thousand years. The biblical account of the origin of Eve, and the opinions of the philosophers of classical Greece, have unexpected bearings on present-day ideas. The scientific study of sex determination can be said to have begun in the 17th century with the discovery of spermatozoa, but the origin and function of the "spermatic animalcules" eluded investigators until 1841. The mammalian egg was discovered in 1827, and in the last quarter of the century fertilization was observed. The view current at that time, that sex determination was under environmental control, gave way to the idea of chromosomal determination in the first quarter of the 20th century. The study of human and other mammalian chromosomes during the third quarter of the century, and the discovery of sex-chromosome abnormalities, emphasized the importance of the $Y$ chromosome for male sex determination. The last quarter of the century witnessed a hunt for the "testis-determining" gene, thought to be responsible for the differentiation of Sertoli cells, and culminating in the isolation of SRY (Sry in the mouse). However, an increasing number of additional genes and growth factors were found to be required for the establishment of male sex. During the same period evidence emerged that male development was accompanied by enhanced growth, both of gonads and whole embryos. An unexpected finding was the demonstration of temperature-dependent sex determination in reptiles. With the advent of the 21 st century, it was shown that Sry induces cell proliferation in fetal mouse gonads, and it has been suggested that male sex differentiation in mammals requires a higher metabolic rate. These insights could lead to a better understanding and improved treatment of abnormalities of sexual development. (Arq Bras Endocrinol Metab 2005;49/1:7-13)

Keywords: Sex determination; Sex chromosomes; SRY; Sertoli cells; Growth; Cell proliferation

\section{RESUMO}

\section{Determinação Sexual em Mitologia e História.}

A história das idéias sobre a origem da divisão entre sexo masculino e feminino tem pelo menos três mil anos. A explicação bíblica para a origem de Eva e as opiniōes dos filósofos da Grécia antiga relacionamse de forma surpreendente com as idéias atuais. Pode-se dizer que 0 estudo científico da determinação do sexo iniciou-se no século XVII com a descoberta dos espermatozóides, mas sua origem e função somente foram desvendadas em 1841. O óvulo dos mamíferos foi descoberto em 1827, e no último quarto desse século a fertilização foi observada. A visão corrente naquela época, de que a determinação do sexo estava sob controle do ambiente, deu lugar à idéia da determinação cromossômica no primeiro quarto do século XX. O estudo dos cromossomos dos seres humanos e de outros mamíferos no terceiro quarto desse século e a descoberta de aberrações dos cromossomos sexuais enfatizaram a importância do cromossomo Y para a determi- revisão

Ursula Mittwoch
Galton Laboratory, Department of Biology, University College London, UK. 
nação sexual masculina. O último quarto do século XX testemunhou a caçada ao gene da determinação testicular, que seria responsável pela diferenciação das células de Sertoli, culminando no isolamento do gene SRY (Sry no camundongo). Entretanto, constatou-se que outros genes e fatores de crescimento, em número cada vez maior, são necessários para o estabelecimento do sexo masculino. Nesse mesmo período surgiram evidências de que o desenvolvimento masculino acompanhase de crescimento acentuado, tanto das gônadas quanto de todo o embrião. Um achado inesperado foi a demonstração de que a determinação sexual em répteis é dependente da temperatura. Com o advento do século XXI, demonstrou-se que o Sry induz a proliferação celular nas gônadas fetais de camundongos, e tem sido sugerido que a diferenciação sexual masculina em mamíferos requer uma taxa metabólica mais alta. Esses insights podem levar a uma melhor compreensão e a um aperfeiçoamento do tratamento dos distúrbios da diferenciação do sexo. (Arq Bras Endocrinol Metab 2005;49/1:7-13)

Descritores: Determinação sexual; Cromossomos sexuais; SRY; Células de Sertoli; Crescimento; Proliferação celular

$\mathbf{N}^{\circ}$ TWO HUMAN BEINGS are exactly alike. On the contrary, they differ in a host of major and minor differences. Even in an age of egalitarianism it is surely evident that the difference that divides us into males and females is truly fundamental, which is reflected in many of our every-day languages. The personal pronouns "he" and "she" in English reflect the gender of the person to which they apply, as do the Portuguese "ele" and "ela". No other personal differences are thus distinguished.

Once awareness of the division into males and females had been reached the question arose of how this came it about. This question received many different answers. Debates on the origin of the sexes took place long before the beginning of the scientific era and provide an insight into the culture of the times. Some early accounts fall into the category of myths, that is to say narratives that are not based on facts but embody some popular idea concerning natural phenomena. Popular ideas must never be underestimated, and they may indeed sometimes serve as a corrective to scientific concepts; for though the latter are based on facts, there are rarely enough facts available, and extrapolation is rife.

\section{The Story of Genesis and Related Tales}

In the first book of the Bible, the book of Genesis, we read that God created Eve, the first woman, from one of Adam's ribs (Genesis 2: 21-24). But although this statement has become part of popular culture, it is by no means certain that it is based on a correct interpretation of the original text. The Old Testament was written in Hebrew, and the word zela, which is usually translated by "rib" in this context, can also means "side" - an uncertainty of meanings that is also seen in European languages. Thus the Latin word costa can mean "rib", "flank" or "side", and the "coast-of the sea" is the "sea-side" (1).

There is a long tradition that "side" is the correct meaning in the Adam-and-Eve story. It means that the first "couple" were not actually a couple but a hermaphrodite being, who was intended to reproduce by self-fertilization. But God saw that this was not good, and proceeded to bisect Adam into a male and a female half. This major operation enables us to understand the verse that follows immediately after creation of Eve: "Therefore shall a man leave his father and his mother and cleave unto his wife" (Genesis ii, 24) (2). Would a man leave his parents because he has lost a rib? On the other hand, once he realizes that he has lost his other half, it is a logical to go out and seek her in order to be re-united with her.

A bisected Adam links the biblical story to the account in Plato's Symposium, where Aristophanes recounts the origin of the sexes. Aristophanes actually recognizes three sexes, male, female and hermaphrodite in order to account for the origin of homosexuality. The primeval man was round, with four hands and four feet, and he had two faces looking in opposite directions. These men were exceedingly strong and mighty and presented a threat to the gods. Therefore Zeus devised a plan of enfeebling them by cutting them in half; but as soon as the two halves were separated, they came together again in mutual embraces.

The same tradition runs through the myths of India and Persia. There is evidence that the idea of an hermaphrodite origin of man and his subsequent bisection is more than 5000 years old (3). It is certainly a more egalitarian tradition than the story of the rib.

\section{Sex Determination in Classical Greece: Heat, Right and Left}

Egalitarianism was not a feature of Classical Greece. In the 2 nd century AD, the Greek physician Galen summed up the classical opinion as follows: "Now just as mankind is the most perfect of all animals, so within mankind the man is more perfect than the woman, and the reason for the perfection is his excess of heat, for heat is Nature's primary instrument. Hence in those animals that have less of it, her workmanship is necessarily more imperfect, and so it is no wonder that the 
female is less perfect than the male by as much as she is colder than he" $(4,5)$.

The idea that males are hotter than females is attributed to the Greek philosopher Empedocles (ca. 494-434 BC), who also postulated that organisms are composed of the four elements: fire (hot), air (moist), water (cold) and earth (dry).

These variables formed the basis for a model of sex determination proposed by Aristotle (384-322 $\mathrm{BC}$ ) that the male is characterized by an abundance of the superior element fire, whereas the female has an abundance of water, and is therefore rather cold $(6,7)$.

The superiority of the male over the female is paralleled by the superiority of the right over the left side, and by assuming that the right side is hotter than the left, a consistent theory of sex determination is arrived at: males are formed on the right and females on the left side $(6,8)$. According to Parmenides (ca. $515 \mathrm{BC}$ ), the sex of the embryo was determined by the side of the womb in which it developed, whereas Anaxagoras (ca. 500-428 BC) thought that the side of the father's testis was the deciding factor. Aristotle criticized both theories, citing evidence that in animals, embryos of both sexes can be found in the same side of the uterus, and that men with only one testis can father children of both sexes. However, the leftright hypothesis of sex determination withstood such factual objections and has been current until recent times - surely an unbeatable record!

Even more strange is that recent evidence suggests that the hypothesis contains an element of truth, albeit a small one. In patients with true hermaphroditism, testicular tissue, i.e. testes and ovotestes, are preferentially situated on the right side, while most ovaries occur on the left (9).

\section{Unravelling the Mystery of Reproduction}

For nearly 2000 years, intuition remained the only tool available for gaining an understanding of the mechanism of reproduction. Its actual basis, the reproductive cells, could not even be conjectured in the absence of microscopes and special techniques to visualize them. Of course, the eggs of birds and various other animals were known since the beginning of human history. But what is the role of the father? Or that of the mother in humans and other mammals? The tortuous road towards understanding these mysteries began in the 17 th century $(10,11)$.

A significant step forward was the discovery by Antonie van Leeuwenhoek (1632-1723) of the "spermatic animalcules" in men and dogs, which he described in a letter to the Royal Society in London
1676. This established that the mysterious substance, semen, was inhabited by a multitude of tiny eel-like little animals. But where did they originate, and what was their function? The animalcules became subject of controversy that lasted more than one and a half centuries (10).

Leeuwenhoek claimed that the animalcules played a vital role in the formation of the embryo by providing its substance, in contrast to the egg which served as nourishment. This idea seemed to run counter to the current doctrine that all organisms originate from an egg. William Harvey maintained that this rule applied even to viviparous animals (12), even though his researches on the fallow deer failed to show any connection between the developing embryo and the mother's ovaries (13). In 1651 he published a book, Exercitationes anatomicae de generatione animalium. The frontispiece in two of the book's editions contained the aphorism Ex ovo omnia, which helped to popularize the idea and was much misquoted (10).

More evidence about the mammalian egg was provided by Reinier de Graaf (1641-1673), whose publication on the female organs of generation was published in 1672 (10). Graaf dissected rabbits at various intervals after mating and had some success in tracing the "eggs" during their passage from the ovary via the oviduct to the uterus. He realized that the ovum in the oviduct was smaller than the follicles that now bear his name, although he never saw the ovum. On the other hand, he concluded that the mammalian ovaries are directly comparable to those of birds, and this recognition further advanced the idea that the embryo is formed from an egg rather than a spermatic animalcule.

Nevertheless it took another century and a half before the mammalian egg was actually discovered. In 1827, Carl von Baer (14) published his work on mammalian and human eggs, in which he described and illustrated the ovum inside the Graafian follicle, thus demonstrating the truth of Harvey's aphorism one and a half centuries after it was proposed.

As regards the spermatic animalcules, von Baer was of the opinion that they were parasites akin to Infusoria, and he perpetuated this view by naming them "spermatozoa" (10). The riddle of the sperm "animals" was solved by Alfred Kölliker (15) in 1841, who, after examining all manner of invertebrate creatures under the microscope, concluded that spermatozoa are not independent animals but are products of cells in the testis, which needed to come into contact with the egg for successful reproduction. The coming together of the 
nuclei of egg and sperm cells was observed by Oscar Hertwig (16) in 1876.

The mystery of generation having been solved in grand outline, the last quarter of the 19th century witnessed the discovery of chromosomes (11).

\section{Is Sex Determined By The Environment?}

Basically there are two ways in which sex could be determined: either the zygote is predetermined by its constitution to develop into either a male or a female, or sex is gradually imposed by environmental conditions on a zygote of indeterminate sex. At the end of the 19th century the latter view prevailed. Food was thought to be the most decisive of the environmental factors, so that the determination of sex could basically be ascribed to the mother's nutrition, particularly during the first three months of pregnancy (17). A poor nutrition was thought to result in males, better nutrition in females.

Temperature was thought to be less important than nutrition. Summarizing the available evidence, Geddes and Thomson (18) concluded that many factors co-operate in the determination of sex, and those adverse conditions, particularly of nutrition, but also of temperature, tend to produce males, while favorable conditions result in females.

These conditions were thought to act on parents, sex elements, embryo and sometimes larvae, evidence that no distinction was made between environmental factors influencing the formation of the zygote, its survival, and the development of its sexual characteristics.

At the fin de siècle, L. Cuénot (19) found many of the above claims unconvincing and expressed his dissatisfaction with the science of sex determination as follows: "It is surely humiliating to state that as regards man and other mammals, no advance has been made since the time of the predecessors of Aristotle, even though a considerable amount of work has been expended in trying to solve the problem; evidently the wrong approaches were chosen (translated by UM).

\section{Chromosomes}

Following the rediscovery of Mendel's paper in 1900 (20), the 20th century became the century of genetics. However, the change of concept from environmental to genetic sex determination came about not in terms of genes but of chromosomes.

Already in 1891, Henking, in his description of the cell division leading to spermatocytes in a plant bug, had illustrated two dissimilar products, only one of which contained a large unusual element, labelled "X", and in 1902 McClung proposed that this "acces- sory chromosome" was involved in the determination of sex (reviewed in 21).

Two investigators in particular obtained evidence in favour of the role of chromosomes in sex determination. E.B. Wilson (22) found that in different species of insects, spermatocytes differed either in the presence or absence of one chromosome, or in the size of one of the chromosome pairs. Netty Stevens (23) investigated both sexes of the common mealworm, Tenebrio molitor, and found that in males, but not females, one chromosome was smaller than the others, and she concluded that this chromosome must be responsible for the determination of male sex. The smaller chromosome became known as "Y", the larger one as "X" (24 1908), and both as "sex chromosomes" (25).

By the end of the end of the first quarter century, TH Morgan (26) recognized three different sexdetermining mechanisms: (1) the "insect type" XX/XY; (2) its variant $\mathrm{XX} / \mathrm{XO}$; (3) the apparently contrary "avian type", which also included Lepidoptera, $\mathrm{ZZ/ZW}$. Morgan also pointed out that the genetic evidence showed that humans must be either $\mathrm{XX} / \mathrm{XY}$ or $\mathrm{XX} / \mathrm{XO}$. Cytological evidence obtained during the second quarter of the century made the presence of a $\mathrm{Y}$ chromosome increasingly likely (27), and marked improvements in cytological techniques in the third quarter turned the likelihood into certainty (28).

In addition to establishing the human sex-chromosome mechanism, the new techniques soon led to the discovery of sex-chromosome anomalies, notably XXY in Klinfelter's syndrome (29) and a single X and no Y in Turner's syndrome (30). Since patients with Klinefelter's syndrome present as males and those with Turner's syndrome as females, these findings provided strong evidence that the $\mathrm{Y}$ chromosome performs an important function in the development of the human male. But what is this function?

\section{The Search For The "Testis-Determining Gene"}

The last quarter of the 20th century witnessed a sustained hunt for the hypothetical "testis-determining" gene on the Y chromosome, named TDF (for "testisdetermining factor") in humans, and Tdy in the mouse. The choice of the testis as the male icon was based on the idea popularized by Alfred Jost (31) that embryos develop in a non-sexspecific manner until the hitherto indifferent gonad becomes a testis. It then secretes hormones which masculinize the reproductive tract. Subsequently Jost and colleagues (32) reported that the Sertoli cell is the first morphologically detectable cell, thus pinpointing the 
presumed function of $T D F / T d y$ to switching hitherto uncommitted somatic gonadal cells to become Sertoli cells.

Previous evidence had indicated that the human gene should be on the short arm of the $\mathrm{Y}$ chromosome (33). Subsequent searches resulted in a number of candidate genes whose candidature was later revoked (34). They include H-Y antigen, the repeated sequence, $B k m$, and the zinc-finger gene, ZFY. The search ended with the isolation of SRY from the human $\mathrm{Y}$ chromosome, the cloning of a corresponding gene, Sry, in the mouse, and the demonstration in 1991 that the addition of Sry as a transgene could cause male development in XX mouse embryos (reviewed in 34).

An important involvement of SRY in male sexual development is not in doubt, but no direct target has been discovered, and the expectation of finding the pathway from gene to phenotype has not so far been fulfilled. In order to understand the function of $S R \Upsilon$, it is necessary to be aware of some other lines of research that took place during the last decades of the 20th century.

\section{Sex Differentiation and Growth}

Side by side with the advances leading to the discovery of sex-determining genes, there have been other lines of research concentrating on quantitative differences between male and female embryos. These have shown that in a variety of mammalian embryos, testes grow faster than ovaries, and that, where the material was available, a difference in size could be detected before histological differentiation was evident, giving rise to the hypothesis that fast growth was a prerequisite for becoming a testis $(35,36)$.

Moreover, evidence accumulated that the enhanced growth of male embryos was not confined to the gonads. Thus, ultrasound examinations of human fetuses showed that males were more advanced in development than females before the testes were hormonally active (37), and XY human embryos produced by in-vitro fertilization averaged more cells than their XX counterparts on day 2 after fertilization (38). These and other findings call for a modification of Jost's (31) principle that the sexes develop in identical fashion until the development of testes; rather they suggest that sex differentiation begins soon after conception (39). While it remains correct that fetal testes exhibit the first histological sign of sex differentiation, a difference in growth rate exists since the beginning of embryogenesis; and even in testes, an enhanced growth rate is detectable earlier than a difference in histology.
It is also relevant to note that during the same period it was discovered that in many reptiles, sex is determined by the temperature of incubation (40). Temperature, of course, exerts a marked effect on rates of growth in ectothernic animals. That sex should be determined by environmental means in vertebrates as highly evolved as reptiles was clearly a surprising finding for scientists working on the genetics of sex determination.

\section{Sry Induces Cell Proliferation, And Growth Fac- tors Are Necessary For Male Sex Differentiation}

The possibility that Sry may initiate the pathway responsible for the size increase of the male gonad was investigated by Schmahl et al. (41), using 5'bromo-2'-deoxyuridine (BrdU) incorporation into dividing cells. The authors reported that an increase in cell proliferation was the first identified effect of gene expression. Other growth factor genes required for testis development include fibroblast growth factor 9 ( $F g f 9)$, platelet derived growth factor receptor alpha (Pdgfra) and insulin growth factor receptors (reviewed in 42). Absence of $\mathrm{Fgf} 9$ results in XY sex reversal, and the same applies to mice lacking all three insulin receptor genes, whereas absence of Pdgfra interferes with the development of Leydig cells.

\section{Conclusion: A New Paradigm}

At the beginning of the 21 st century, we are confronted with a shift in paradigm regarding the basis of sex determination. The idea of a single Y-chromosomal gene responsible for the differentiation of Sertoli cells is giving way to the realization, based on an increasing body of data, that this gene, in cooperation with non-Y-chromosomal genes, increases proliferation in the cells in which it is active. At a more basic level, it has been suggested that the genes that are required for male sex differentiation may effect an increase in metabolic rate, which seems to be a near-universal characteristic of mammalian males (43).

The new paradigm bears an uncanny resemblance to the idea held by the philosophers of Ancient Greece, that males are hotter than females. Could it be that the Ancient Greeks knew something that present-day geneticists are just in the process of discovering?

At any rate, the new understanding that genes for male sex determination act as promoters of growth, and hence must be assumed to interact to some extent with environmental factors, promises to help in 
explaining the different abnormalities of sexual development, and, it may be hoped, will lead to more effective treatments.

\section{REFERENCES}

1. The Oxford English dictionary. Oxford: Clarendon Press; 1989.

2. Mittwoch U. Three thousand years of questioning sex determination. Cytogenet Cell Genet 2000;91:186-91.

3. Krappe AH. The birth of Eve. In: Schindler B, Marmorstein A, editors. Gaster anniversary volume. London:Taylor's Foreign Press; 1936.p.312-22.

4. Galen (translated by May MT). On the usefulness of parts of the body. New York:Ithaca; 1968.

5. Gordon H. Ancient ideas about sex differentiation. In: Vallet, HL. Porter IH, editors. Genetic mechanisms of sexual development. New York:Academic Press; 1979.p. 1-32.

6. Lesky E. Die zeugungs-und vererbungslehren der antike und ihr nachwirken. Abhandlungen der akademie der wissenschaften und der literatur nr. 19. Wiesbaden: Verlag der Akademie der Wissenschaften und der Literatur in Mainz; 1950.

7. Aristotle (translated by Peck AL). Generation of Animals. In: Goold GP, editor. The Loeb classical library. Cambridge:Harvard University Press; 1979.

8. Lloyd GER. Right and left in Greek philosophy. In: Needham $R$, editor. Essays in dual symbolic classification. Chicago \& London:University of Chicago Press; 1973.p. 167-86.

9. Mittwoch U. Genetics of sex determination: exceptions that prove the rule. Mol Genet Metab 2000;71:405-10.

10. Cole FJ. Early theories of sexual generation. Oxford:The Clarendon Press; 1930.

11. Harris $H$. The birth of the cell. New Haven \& London:Yale University Press; 1999.

12. Harvey W (translated by Whitteridge G). Disputations touching the generations of animals. Oxford:Blackwell Scientific Publications; 1981.

13. Short RV. The discovery of the ovaries. In: Zuckerman S, Weir BJ, editors. The Ovary. London:Academic Press; 1977.p. 1-39.

14. von Baer CE. De Ovi mammalium et hominis genesi. Leipzig:Leopold Voss; 1827.

15. Kölliker A. Beiträge zur kenntniss der geschlechtsverhältnisse und der samenflüssigkeit wirbelloser thiere, nebst einem versuch über das wesen und die bedeutung der sogenannten samenthiere. Berlin:Logier; 1841.

16. Hertwig $O$. Beiträge zur kenntnis der bildung, befruchtung und theilung des thierischen eies. Morph Jahrb $1875 ; 1: 347-434$.

17. Düsing C. Die regulierung des geschlechtsverhältnisses bei der vermehrung der menschen, tiere und pflanzen. Jena Zeitschr Naturwiss 1884;17:593-940.

18. Geddes Thomson JA. The evolution of sex. London:Walter Scott; 1889.

19. Cuénot L. Sur la détermination du sexe chez les ani- maux. Bull Sci Fran Belg 1899;32:461-534.

20. Olby R. Origins of mendelism. Chicago \& London:The University of Chicago Press; 1985.

21. Mittwoch U. Heteropycnosis and the activity of sex chromosomes: history and prospects. In: Sandberg AA, editor. Cytogenetics of the mammalian $X$ chromosome. Part A: Basic mechanisms of $X$ chromosome behavior. New York:Alan R Liss Inc.; 1983.p.251-70.

22. Wilson EB. Studies on chromosomes 1. The behavior of the idiochromosomes. J Exp Zool 1905;2:371-405.

23. Stevens NM. Studies in spermatogenesis, with especial reference to the accessory chromosome. Carnegie Inst Wash 1905;36:1-32.

24. Wilson EB. Recent researches on the determination and heredity of sex. Science 1909;29:52-70.

25. Wilson EB. The sex chromosomes. Arch Anat Entwicklungsmech 1911;77:249-71.

26. Morgan TH. The theory of the gene. New York:Hafner Publishing Company; 1964

27. Matthey R. Les chromosomes des vertébrés. Lausanne:Rouge; 1949.

28. Ford CE, Hamerton JL. The chromosomes of man. Nature 1956;178:1020-3.

29. Jacobs PA, Strong JA. A case of human intersexuality having a possible XXY sex determining mechanism. Nature 1959;183:302-3.

30. Ford CE, Jones KW, Polani PE, Almeida JC, Biggs JH. A sex-chromosome anomaly in a case of gonadal dysgenesis (Turner's syndrome). Lancet 1959;711-3.

31. Jost A. Problems of fetal endocrinology: the gonadal and hypophyseal hormones. Rec Progr Horm Res 1953;8:379-418.

32. Jost A, Magre S, Agelopoulou R. Early stages of testicular differentiation in the rat. Hum Genet 1981;58:59-63.

33. Jacobs PA, Ross A. Structural abnormalities of the $Y$ chromosome in man. Nature 1966;210:352-4.

34. Graves JMA. Mammalian sex-determining genes. In: Short RV, Balaban E, editors. The differences between the sexes. Cambridge:Cambridge University Press; 1994.p.397-418.

35. Mittwoch U, Delhanty JDA, Beck F. Growth of differentiating testes and ovaries. Nature 1979;224:1323-5.

36. Mittwoch U. Males, females and hermaphrodites. Ann Hum Genet 1986;50:103-21.

37. Pedersen JF. Ultrasound evidence of sexual difference in fetal size in first trimester. Br Med J 1980;281:1253.

38. Ray PF, Conaghan J, Winston RML, Handyside AH. Increased number of cells and metabolic activity in male human preimplantation embryos following invitro fertilization. J Reprod Fert 1995; 104:165-71.

39. Erickson RP. Does sex determination begin at conception? BioEssays 1997:19:1027-32.

40. Pieau C, Dorizzi M, Richard-Mercer N. Temperaturedependent sex determination and gonadal differentia- 
tion in reptiles. Cell Mol Life Sci 1999;55:887-900.

41. Schmahl J, Eicher EM, Washburn LL, Capel B. Sry induces cell proliferation in the mouse gonad. Development 2000;127:65-73.

42. Schmahl J, Kim Y, Colvin JS, Ornitz DM, Capel B. Fgf9 induces proliferation and nuclear localization of FGFR2 in Sertoli precursors during male sex determination.
Development 2004; 131:3627-36.

43. Mittwoch $U$. The elusive action of sex-determining genes: mitochondria to the rescue? J Theor Biol 2004; 228:359-65.

\section{Endereço para correspondência:}

Ursula Mittwoch

Galton Laboratory

Department of Biology

University College London - Wolfson House

4 Stephenson Way, London NW1 2HE, UK

E-mail: u.mittwoch@ucl.ac.uk 